\title{
Fluid-driven seismicity in a stable tectonic context: The Remiremont fault zone, Vosges, France
}

\author{
Laurence Audin, ${ }^{1,2}$ Jean-Philippe Avouac, ${ }^{1}$ Mireille Flouzat, ${ }^{1}$ \\ and Jean-Louis Plantet ${ }^{1}$ \\ Received 9 February 2001; revised 27 June 2001; accepted 6 September 2001; published 27 March 2002.
}

[1] Some relocated seismic events, which have small magnitudes (ML < 4.8), are found to align along a $40 \mathrm{~km}$-long fault zone flanking the southern Vosges Massif to the west. It joins to the south with the epicentral area of the historical 1682 earthquake (Io = VIII MSK). The Remiremont cluster was preceded by a period of seismic coalescence and triggered outward of bilateral seismic migration. The 1984 seismic crisis developed along a well defined $3 \mathrm{~km}$-long vertical plane. In both cases, migration rates of the order of $5-10 \mathrm{~km} / \mathrm{yr}$ over $30 \mathrm{~km}$-long distances are determined. This pattern requires some mechanism of stress interaction which must act over distances of the order of 1 to $20 \mathrm{~km}$ within years. Given the low tectonic activity and the magnitudes of the events the stress transfer cannot result from co-seismic elastic loading or from transient strain at depth. We suggest that the seismic activity reflect rupture of asperities driven by fluid-flow in a zone of relatively high permeability. INDEX TERMS: 7230 Seismology: Seismicity and seismotectonics; 8045 Structural Geology: Role of fluids; 8107 Tectonophysics: Continental neotectonics; 9335 Information Related to Geographic Region: Europe

\section{Introduction}

[2] Our understanding of seismotectonic processes has greatly improved over the last few decades, essentially thanks to the study of the most active seismic zones around the world. The seismicity of stable tectonic area has attracted less interest and remains poorly understood [e.g. Atkinson et al., 2000 EOS]. There is however a need for a physical rationale that would provide guidelines for seismic hazard assessment in those areas where historical catalogues are known to be incomplete and where the usual techniques in seismotectonics are inappropriate due to the lack of a measurable signal. The most easily accessible information comes from seismic monitoring. Even at places far from zones of active crustal deformation some background seismicity can generally be detected.

[3] The seismicity of France has been monitored by the LDG since 1962 [Nicolas et al., 1990]. The Alps, Pyrenees and Rhine graben are the most active areas and are indeed known to be zones of on-going crustal deformation, although deformation rates are very small [Calais et al., 2000]. Conspicuous seismicity is also observed in Massif Central, Massif Armoricain, Vosges which are generally considered to be stable continental domains (Figure 1). Here, we focus on the seismicity of the Vosges where one of the most damaging earthquakes known to have occurred in France took place in 1682 (see macroseismic epicenter in Figures 1 and 2). This earthquake, which was felt as far away as Versailles, $(400 \mathrm{~km}$ to the west) and destroyed the roof of the Remiremont's church (Io $=$ VIII, MSK), is ascribed a local magnitude of 5,3 [SIRENE, 1998]. Together with the Basel earthquake (1356, Io = IX, MSK),

\footnotetext{
${ }^{1}$ Laboratoire de Géophysique, CEA Bruyères-le-Chatel, France.

${ }^{2}$ Now at I.R.D.-U.P.S. Géologie, 38 rue des 36 ponts, 31400 Toulouse.
}

it is considered as one of the major events to have struck NE France.

[4] In the following, we analyze the instrumental seismic activity and show a particular spatio-temporal pattern that seem to indicate interactions at a scale that exceeds that likely to be caused by co-seismic elastic stress transfer. We finally argue that fluids are probably involved in the process.

\section{Tectonic and Geological Setting}

[5] The Vosges massif lies west of the Rhine Graben which is part of the Cenozoic rift system of Central Europe and has been active tectonically since the late Eocene [Brun and Gutscher, 1992; Ziegler, 1992]. Since the mid Pliocene, activity in the southern Rhine graben has been dominated by left-lateral shear on the N-S faults that parallel the graben axis (Figure 2) [Abhorner, 1975].

[6] The Hercynian Vosges Massif is composed of two regions, the Saxo-Thuringian Vosges and the Modanubian Vosges, which lie respectively south and north of the Lalaye-Lubine fault zone (F2 in Figure 1). In this study, we focus on the southern Vosges, which consist mainly of crystalline rocks (granitoids, migmatites, leucogranites) overlain with Upper Devonian to Dinantian cover [Fluck et al., 1991] (Figure 1). The long geological history has resulted in a complex faults pattern [BRGM, 1999]. The major tectonic feature is the Sainte-Marie-aux-Mines fault which cuts the southern Vosgian Massif from NE to SW (F1 in Figure 1). Although it is conspicuous in the morphology (Figure 2), this fault is considered as an exhumed, now inactive, ductile left-lateral strike-slip fault [Fluck, 1991].

[7] Since the installation of the LDG permanent seismic network in 1962, some seismicity has been recorded in the southern Vosges. The local magnitudes (Ml) range typically between 1 and 4.8, making a typical Gutenberg-Richter distribution with a bvalue of $0.83 \pm 0.03$ (maximum likehood estimate). The seismicity makes a N-NE trending strip that extends from the epicentral area of the 1682 historical event over a distance of about $40 \mathrm{~km}$ (Figure 1).

[8] The coincidence with other minor historical events (Figure 2) shows that it has been a long-lived seismic structure. The seismicity is dominated by two seismic crisis which took place in 1973-1974 and 1984-1985 around the towns of Epinal and Remiremont respectively (Figure 2). The few available focal mechanisms in the area, including those related to the main shocks near Epinal and Remiremont, are consistent with a roughly $\mathrm{N} 30^{\circ} \mathrm{W}$ principal compressive stress $(\sigma 1)$ and $\mathrm{N} 60^{\circ} \mathrm{E}(\sigma 3)$ minimum principal stress [Delouis et al., 1993; Mueller et al., 2000] consistent with the World stress map that suggest a stress tensor driven by the Alpine collision.

\section{Relocation of Instrumental Seismicity}

[9] In order to analyze its spatio-temporal characteristics, the seismicity was relocated more precisely. We selected a set of 350 events recorded by at least 3 permanent LDG stations. Arrival time data from each shock were used for the relative positions of the events using a hypocentroidal decomposition method [Pavlis and 


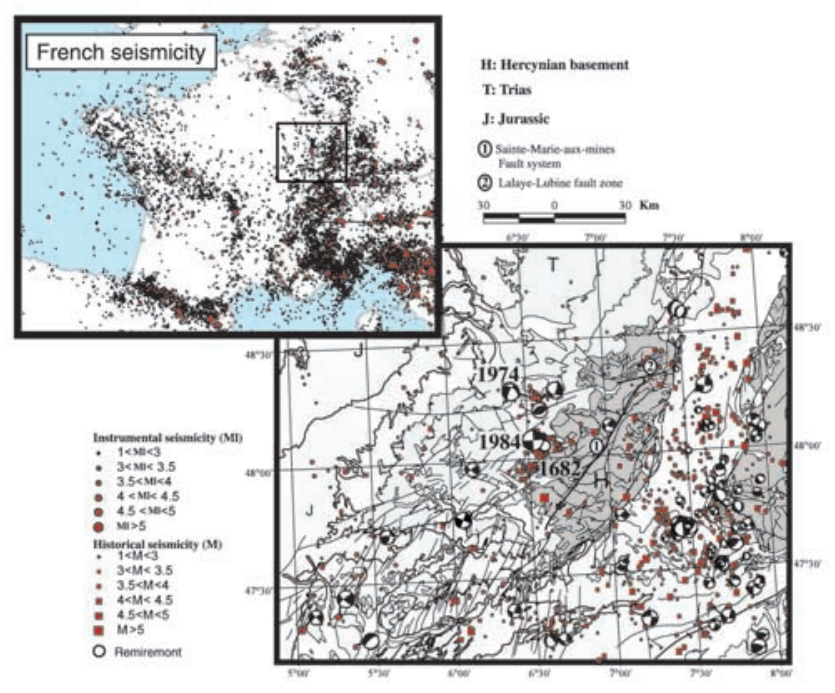

Figure 1. BRGM Geological map from north east France, region of the southern Vosges Massif. Major identified fault traces are reported in black, names given by numbers. Green dots represent the instrumental seismicity recorded continuously by the LDG network since the year 1964. Historical events are reported in yellow polygons. Focal mechanisms after [Plenefisch and Bonjer, 1997; Nicolas et al., 1990; Delouis et al., 1993; Bonjer, 1997; Lachaize, 1982]. 330 small earthquakes were detected by the LDG seismic network from 1964 to 1999 (Figures 1-2) and we reported the historical earthquakes from the [SIRENE, 1998] database, back to year 849 .

Booker, 1983]. The relocation technique is based on relative arrival times, with time corrections determined from a set of master events [Pavlis and Booker, 1983]. This method uses arrival times from different events at the same station to constrain earthquake relative positions within a limited source region, thus minimizing the effect of velocity heterogeneity along the ray paths. We used 2 master events located from at least $10 \mathrm{P}$-wave arrival times, and with a good azimuthal coverage. The locations relative to the master events are then determined using a 1-D velocity model [Delhaye and Plantet, 1976]. The $2 \sigma$ uncertainty on epicenter location using this technique is estimated to be 1 to $2 \mathrm{~km}$. Depth determinations remain poorly constrained and have uncertainties of the order of $\pm 5 \mathrm{~km}$.

[10] A subset of data, corresponding to the Remiremont seismic crisis, have be relocated from waveform correlation technique, using one master event, [Plantet and Cansi, 1988] because the events were sufficiently close to one another compared to the distance to the local network. Using such waveform cross-correlation methods was successful to achieve high location accuracy, especially in depths. The resulting relative locations are precise to better than $250 \mathrm{~m}$ in general. These events are shown in red in Figures $2 \mathrm{a}$ and $2 \mathrm{~b}$.

\section{Results}

[11] The relocated events cluster along a relatively narrow $\mathrm{N} 20^{\circ} \mathrm{E}$ trending zone, about $3 \mathrm{~km}$ wide, that extends for nearly $25 \mathrm{~km}$ from Val d'Ajol to Eloyes. The 1984-1985 Remiremont crisis occurred at the northern extremity of this zone. The relocated events were found to align along a N-S $3 \mathrm{~km}$ segment. This crisis was also monitored from a local telemetered seismic network [Haessler and Hoan-Trong, 1985], which yielded depths constrained to better than about $500 \mathrm{~m}$. Most hypocenters were obersved to fall on a vertical plane at depths between 6 and 8 $\mathrm{km}$ [Haessler and Hoan-Trong, 1985]. Such a distribution is consistent with left-lateral slip on a vertical plane as suggested from the focal mechanism of the $\mathrm{Ml}=4.8$ main event in 1984 (Figure 1). Note however, that the seismic sequence differs significantly from that expected for aftershocks triggered an elastic co-seismic stress distribution [e.g., King et al., 1994]. First it extends along a linear segment rather than being distributed within lobes of increased Coulomb stress. Second it extends to $1-2 \mathrm{~km}$ of the epicenter where stress variation are probably smaller than 0,01 to 0,05 bar (computed for a $0,1 \mathrm{~cm}$ displacement on a $10 / 100 \mathrm{~km} 2$ fault plane) whereas afterschocks are generally mostly confined to the area where Coulomb stress variations are in excess of 0.1 bar [e.g., King et al., 1994].

[12] The seismicity during the Remiremont crisis (inset in Figure 2) roughly follows the scarp along the western bank of the Moselle valley, but there is no clear continuous morphological feature that can be associated with the seismic zone at a larger scale.

[13] The Val d'Ajol-Remiremont seismic zone more or less connects to the north with another cluster near Epinal that trends about $30^{\circ} \mathrm{W}$ (Figure 2). Most of the events in this cluster relate to the 1972-1974 crisis. Again, there is no obvious correlation with known geological faults or morphological features.

\section{Spatio-Temporal Characteristics of the Seismicity}

[14] Given that most of the seismicity clusters on a roughly NS zone, the temporal pattern may be investigated by simply plotting the epicentral latitude as a function of time (Figure 3). Actually, such a plot is difficult to read because the sismicity is not evenly distributed with time. We use the event number in the sequence as an abscissa (Figure 3). We observe a general migration to the south. Several periods can be distinguished however. From 1964 to 1978 , most of the seismicity is confined in the Epinal area ( $a$ and $b$ in Figure 3). After about 1971 the seismicity intensifies and remains confined to a small segment, less than 1-2 km long.
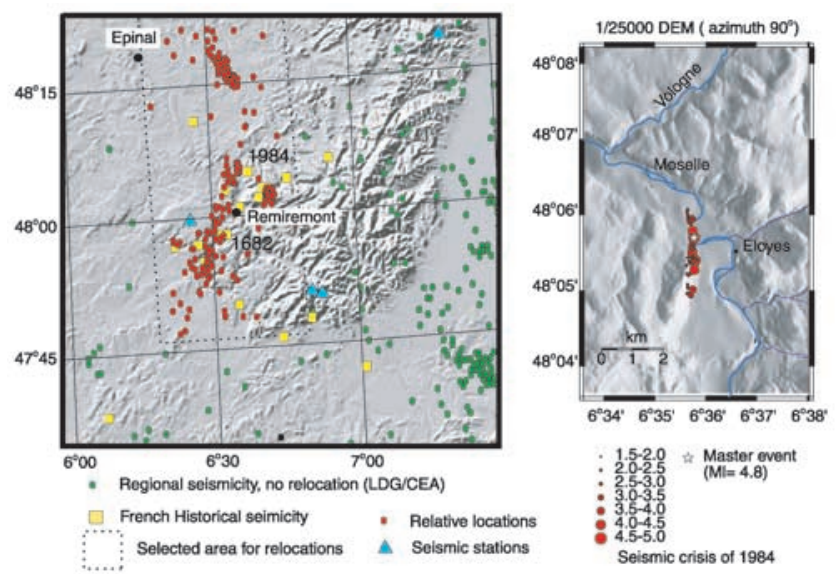

Figure 2. Shaded DEM from the north east of France, region of the southern Vosges Massif. Red dots represent the selected events for relocalisations and the red frame show the area where we investigated for seismo-tectonic structures in this issue; Green dots, the instrumental seismicity recorded continuously by the LDG network since the year 1964, relocated. Historical events are reported in yellow triangles. Blue squares show the position of the three LDG seismic stations, which allow to record the minor events. Inset show the surrounding area of the 1984 seismic events and a detailed DEM showing no trace of any superficial deformation associated to a NS cumulative scarp, cutting through the Moselle recent sediments. Note that interepicenter separations is below the order of the location error $( \pm 5 \mathrm{~km})$. 


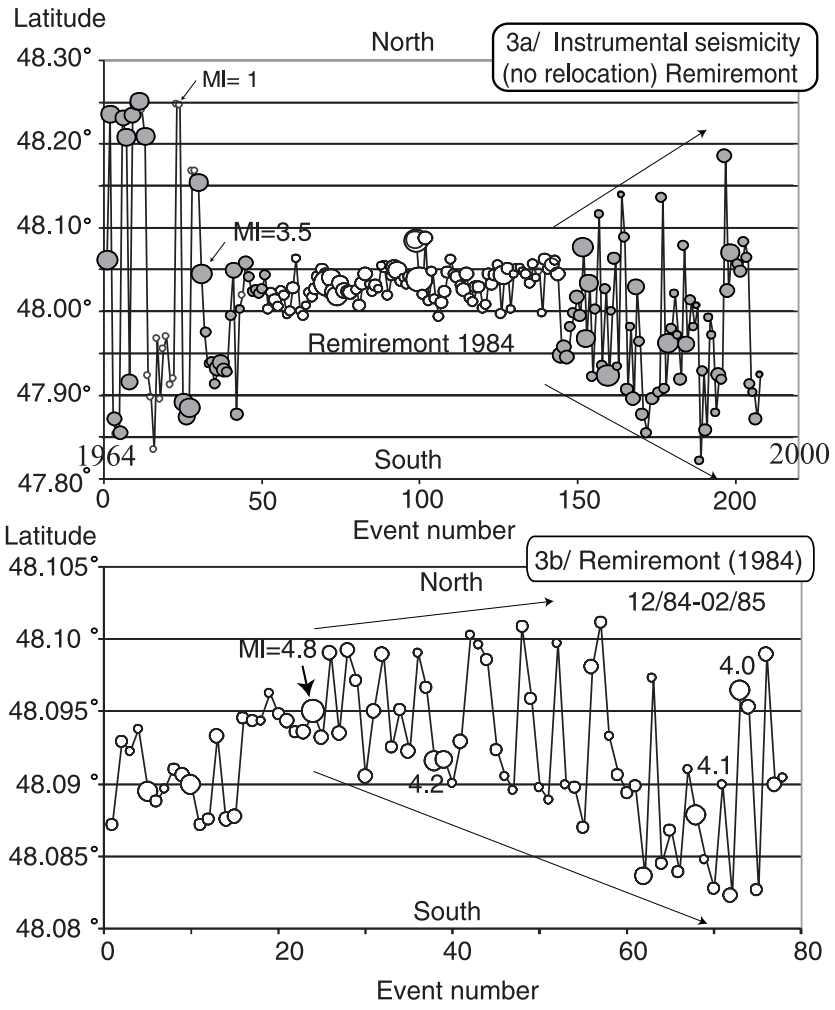

Figure 3. Spatial and chronological seismicity patterns. In order to help assessing the migration-clustering pattern we have plotted the 1964-1999 sequence of epicentral latitudes in the Remiremont area, those events are not relocalized (Figure 3a). We also show a close up view at the pattern made by the afterschocks that are be relocated using the doublet technique (between 12/1984 an 11/02; Plantet and Cansi [1988]) (Figure 3b). On both graphs; the event are sorted by number, without taking time intervals in account. Focal mechanisms after Bonjer et al. [1984]; Lachaize [1982]; Nicolas et al. [1990].

The period between 1978 and 1984 corresponds to a reorganization of the seismicity pattern. The seismicity keeps going on near Epinal and, starting in 1980, suddenly migrates to the south at a rate of about $5-10 \mathrm{~km} / \mathrm{yr}$.

[15] Starting around 1978, some seismicity lights up well to the south of Epinal, at latitudes around $47.9^{\circ} \mathrm{N}$ in Figure 4, and then migrates to the north between 1980 and 1984 . The two branches merge at latitudes around $48^{\circ} \mathrm{N}$. Note that during this period of migration the seismicity delineates a particularly narrow zone. Between 1984 and 1991, the seismicity is confined to the Remiremont area. The Remiremont seismic swarm started by the end of 1984 , with a main shock on the 29 december $1984(\mathrm{Ml}=4.8)$. After 1991 the seismicity migrates farther to the south, activates a swarm around latitude $47.9^{\circ} \mathrm{N}$ until about 1996 , and then becomes more diffuse (Figure 4).

[16] In order to assess the migration-clustering pattern we have plotted the 1964-1999 sequence of epicentral latitudes in the Remiremont area (Figure 4a). We can see that before the 19841985 Remiremont cluster; the seismicity tends to converge, remains clustered but then spreadout after about 6 years. A close up view of the pattern made by the aftershocks that could be relocated using the doublet technique (Figure $3 b$ ), shows the main shock (29/12/1984) also triggered a bilateral migration pattern over a distance of $1-2 \mathrm{~km}$ in two months (corresponding to a migration rate of a few $\mathrm{km} / \mathrm{yr}$ ). This migration stopped and the seismicity remained clustered in the Remiremont area until about mid 1991.
At this stage it again spread bilaterally and activated the swarm around $47.95^{\circ} \mathrm{N}$

\section{Discussion and Conclusion}

[17] Although the details of the spatio-temporal pattern are complex some simple features can be noted. First, periods of migration and periods of clustered activity seem to alternate. During periods of clustered activity seismicity gets more intense and activates a relatively small zone such as during the Epinal and Remiremont crisis. Second point is that during migration seismicity is confined to a relatively narrow zone. These two features suggest that the seismicity is organized at the scale of the studied area. The 1-D migration pattern suggests that stresses are transferred along some kind of fault zone, although none could be clearly identified.

[18] Migration patterns are commonly observed in active tectonic area. Depending on the geometry of the seismic zone and on migration rates they are generally taken to reflect co-seismic stress redistribution [Nalbant et al., 1998], viscoelastic deformation of the lower crust and uppermantle [Sanders, 1993], or fluids flow e.g. [e.g. Miller et al., 1996; Noir et al., 1997; Jacques et al., 1999]. The size of the seismic area in the southern Vosges is large compared to the small magnitudes ( $\mathrm{Ml}$ of the order of 1 to 4.8). It makes it improbable that this organization results from co-seismic stress interactions. In the case of the southern Vosges there is no clear fault zone and deformation rates are very low. We therefore think that deformation of the lower crust and uppermantle cannot be advocated.

[19] Unexpectedly our observations show parallels with the pattern of seismicity observed on the San Andrea's fault near Parkfield where evidence for the involvement of fluids have been found [e.g., Johnson and McEvilly, 1995]. Small earthquakes with magnitude less than 4 form clusters that break in migration sequence.

[20] We similarly propose that the organization of the seismicity pattern in the southern Vosges results from the connectivity of fluids. The linear seismicity would reflect a zone of low permeability that would allow the propagation of transient pore pressure changes. The periods of cluster activity might be ascribed to periods of pore pressure increase around barriers. Migration is

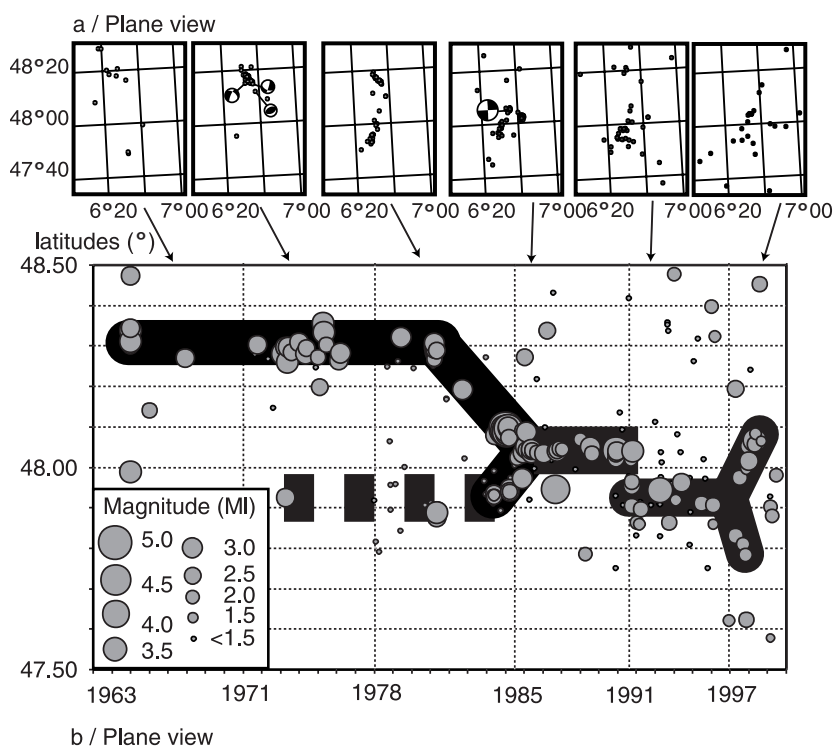

Figure 4. Spatial and temporal seismicity patterns, 5 time windows. The seismicity tend to converge, remains clustered and then spread out after some years. 


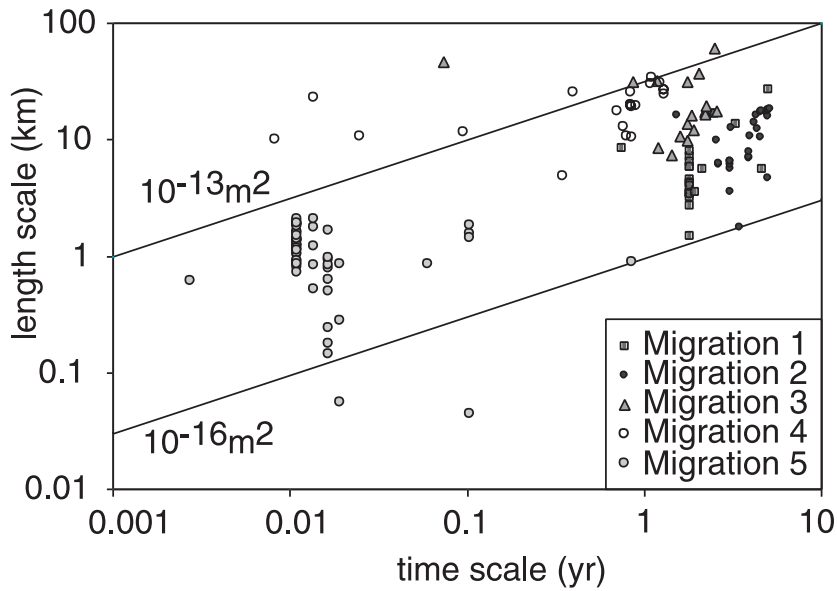

Figure 5. Permeability estimation of the crystalline substratum of Southwestern Vosges. Induced seismicity experiments at Soultz sous Forets indicate that the brittle crust in intraplate regions such as France can be stressed, pore pressures are close to hydrostatic, and in situ bulk permeability is $\sim 10-15$ to $10-16 \mathrm{~m} 2$ to compare to our results [after Townend and Zoback, 2000].

then stopped until the permeability barrier has totally ruptured. Given the characteristic time and length if this diffusive process, we calculated equivalent permeabilities in or zone.Permeability at the scale of 1 to $10 \mathrm{~km}$ in Remiremont area is typically of the order of $10-13$ to $10-16 \mathrm{~m} 2$ [Townend and Zoback, 2000], and such values were actually found from the hydrothermal experiments at Soultz in the northern Vosges [Shapiro et al., 1997] (Figure 5). During hydraulic fracturing experiments at Soultz-sous-Forets site, the local network recorded more than 9000 microseismic events. Those events have been induced in a spatial domain of $1000 \mathrm{~m}$ around the well. These micro earthquakes are considered to trace the diffusion of the pore pressure in the granitic fractured substratum. It is characterised by a circulation of fluids between the Triassic flat sedimentary cover and the fractured underlying Hercynian basement, which is probably also the case on the western flank of the Vosges. In addition, the permeability values obtained at Soultz are in agreements with those calculated for the Epinal-Remiremont and are of the order of 10-15 $\mathrm{m} 2$ [Scott Phillips, 2000].

[21] It has to be noticed that the earthquakes alignment is located just at the outcropping boundary between the Hercynian basement and the Mezozoic horizontal cover. Those horizontal sediment formation could guide fluid circulation toward the crystalline basement, where infiltration could occur along preexisting vertical fissures. At places, cristallisation processes may contribute to sealing pockets of fluids where pore pressure could then build up. It is improbable that pore pressure increase might be driven by some kind of interseismic shear as proposed along an active fault zone [Sleep and Blanpied, 1992].

[22] We therefore suggest that fluid pressure must build up differently, possibly in response to dissolution-recristallisation processes, or thermal processes.

[23] Acknowledgments. This paper has benefited from comments by two anonymous reviewers, and from discussions with Marc Nicolas.

\section{References}

Abhorner, L., Present day stress field and seismotectonic block movements along major fault zones in Central Europe, Tectonophysics, 29, 233-249, 1975.

Atkinson, G., Reassessing the New Madrid seismic zone, Eos Trans. $A G U$, $81,35,2000$.

Bonjer, K. P., Seismicity pattern and style of seismic faulting at the eastern borderfault of the southern Rhine Graben, Tectonophysics, 275, 41-69, 1997.

Bonjer, K. P., C. Gelbke, B. Gilg, D. Rouland, D. Mayer-Rosa, and B. Massinon, Seismicity and dynamics of the Upper Rhinegraben, Journal of Geophysics, 55, 1-12, 1984.

BRGM, Carte Géologique de la France, scale 1/1,000,000 ( $6^{\circ}$ édition) 1999.

Brun, J. P., and M. A. Gutscher, DEKORP-ECORS teams, Deep crustal structure of the Rhine Graben from DEKORP-ECORS seismic reflection data: A summary, Tectonophysics, 208, 139-147, 1992.

Calais, E., L. Galisson, J.-F. Stéphan, J. Delteil, J. Deverchère, C. Larroque, B. Mercier de Lépinay, M. Popoff, and M. Sosson, Crustal strain in the Southern Alps, 1948-1998, Tectonophysics, 319, 1-17, 2000.

Delhaye, A., J. L. Plantet, Sismicité générale de la France, Bull. Soc. Géol. France, 7, tome XVIII, 5, 1095-1102, 1976.

Delouis, B., H. Haessler, A. Cisternas, and L. Rivera, Stress tensor determination in France and neighbouring regions, Tectonophysics, 221, 413437, 1993

Fluck, P., A. Pique, J.-L. Schneider, and H. Whitechurch, Le socle Vosgien, Sci Géol. Bull, 44(3-4), 207-235, Strasbourg, 1991.

Haessler, H., and P. Hoan-Trong, La crise sismique de Remiremont (Vosges) de décembre 1984: Implications tectoniques régionales, C. $R$. Acad. Sc. Paris, Série II, 14, 671-675, 1985.

King, G. C. K., R. S. Stein, and J. Lin, Static stress changes and the triggering of earthquakes, Bull. Seism. Soc. Amer., 84(3), 935-953, 1994.

Jacques, E., J. C. Ruegg, J. C. Lépine, P. Tapponnier, G. C. P. King, and A. Omar, Relocation of $\mathrm{M} \geq 2$ events of the 1989 Dobi seismic sequence in Afar: Evidence for earthquake migration, Geophys. J. Int., 138, 447-469, 1999.

Johnson, P. A., and T. V. McEvilly, Parkfield seismicity: Fluid driven?, J. Geophys. Res., 100(b7), 12,937-12,950, 1995.

Lachaize, M., La sismicité instrumentale (1962-80) de la région LimagnesJura Souabe et ses implications tectoniques, PhD, 1982.

Miller, S. A., A. Nur, and D. L. Olgaard, Earthquakes as a coupled shear stress-high pore pressure dynamical system, Geophys. Res. Lett., 23(2), 197-200, 1996.

Mueller, B., J. Reinecker, K. Fuchs, The 2000 release of the World Stress Map, avalaibale online at http:/www-wsm.physik.uni-karlsruhe.de, 2000 .

Nalbant, S. S., A. Hubert, and G. C. P. King, Stress coupling between earthquakes in northwest Turkey and the north Aegean Sea, J. Geophys. Res., 103(10), 24,469-24,486, 1998.

Nicolas, M., J. P. Santoire, and P. Y. Delpech, Intraplate seismicity: New seismotectonic data in Western Europe, Tectonophysics, 179, 27-53, 1990.

Noir, J., E. Jacques, S. Bekri, P. M. Adler, P. Tapponnier, and G. C. P. King, Fluid flow triggered migration of events in the 1989 Dôbi earthquake sequence of Central Afar, Geophys. Res. Lett., 24, 2328-2335, 1997.

Pavlis, G. L., and J. R. Booker, Progressive multiple event location (PMEL), Bull. Seis. Soc. Amer., 73, 1753-1777, 1983.

Plantet, J. L., and Y. Cansi, Accurate epicenters location with a large network example of the 1984/1985 Remiremont Sequence, in Seismic hazard in Mediterranean Regions, 347-358, 1988.

Plenefisch, T., and K.-P. Bonjer, The stress field in the Rhine Graben area inferred from earthquake focal mechanisms and estimation of frictionnal parameters, Tectonophysics, 275, 71-97, 1997.

Sanders, C. O., Interaction of the San Jacinto and San Andreas fault zones, Southern California: Triggered earthquake migration and coupled recurrence intervals, Science, 260, 973-976, 1993.

SIRENE, Sismicité historique de la France, CEA/IPSN-BRGM-EDF, 1998. Scott Phillips, W., Precise Microearthquake Locations and Fluid Flow in the Geothermal Reservoir at Soultz-sous-Forêts, France, Bull. Seism. Soc. of Amer., 90(1), 2000.

Shapiro, S. A., E. Huenges, and G. Borm, Estimating the crust permeability from fluid-injection-induced seismic emission at the KTB site, Geophys. J. Int., 131, F15-F18, 1997.

Sleep, N. H., and M. L. Blanpied, Creep, compaction and the weak rheology of major faults, Nature, 359, 687-692, 1992.

Townend, J., and M. D. Zoback, How faulting keeps the crust strong, Geology, 28(5), 399-402, 2000.

Ziegler, P. A., European Cenozoic rift system, Present-day deformation of the French northwestern Alps/Southern Jura mountains: Comparison between historical triangulations, Tectonophysics, 208, 91-111, 1992.

L. Audin, J.-P. Avouac, M. Flouzat, and J.-L. Plantet, CEA/DAM/ DASE/LDG/TRS, BP12, 91680 Bruyères le Chatel, France. (audin@lmtg. ups-tlse.fr; avouac@dase.bruyeres.cea.fr; flozat@dase.bruyeres.cea.fr; plantet@dase.bruyeres.cea.fr) 